\title{
EXPERIMENTALWORKS
}

UDC 577.352.4

doi: https://doi.org/10.15407/ubj93.03.005

\section{REGULATION OF IONIZED CALCIUM \\ CONCENTRATION IN MITOCHONDRIA MATRIX \\ IN THE ABSENCE OF EXOGENOUS Ca ${ }^{2+}$}

\author{
A. V. SYLENKO ${ }^{凶}$, S. G. SHLYKOV, L. G. BABICH, \\ O. YU. CHUNIKHIN, S. O. KOSTERIN
}

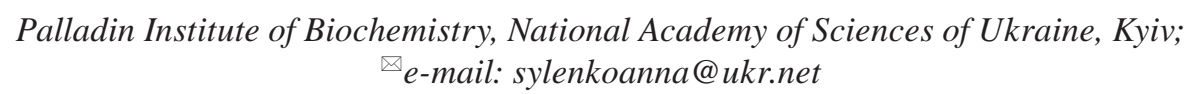

Received: 15 September 2021; Accepted: 17 May 2021

Functional activity of mitochondria depends on ionized calcium content in its matrix. Thus, investigation of the ways to influence $\mathrm{Ca}^{2+}$ transport and accumulation in these organelles is an urgent issue. The aim of this work was to evaluate ionized calcium concentration in the mitochondria matrix in the absence of exogenous $\mathrm{Ca}^{2+}$ and in the presence of $\mathrm{Mg}^{2+}$ and ATP in incubation media. The concentration of ionized calcium in mitochondria isolated from the myometrium of non-pregnant rats was measured with the fluorescent probe Fluo-4 AM, mitochondria hydrodynamic diameter was assessed using dynamic light scattering. The ATP concentration-dependent increase in ionized calcium concentration in mitochondria matrix in the absence of exogenous $\mathrm{Ca}^{2+}$ and the high level of the total $\mathrm{Ca}^{2+}$ accumulation after further addition of exogenous $\mathrm{Ca}^{2+}$ were registered. The effect of ATP on $\mathrm{Ca}^{2+}$ concentration did not depend on the blockage of mitochondrial PTP with cyclosporine $\mathrm{A}$ or on $\mathrm{H}^{+}$-ATPase/ATP-synthase inhibition with oligomycin, instead the addition of $10 \mathrm{mM}$ theophylline and $30 \mathrm{mM} \mathrm{NaHCO}_{3}$ to the $\mathrm{Mg}^{2+}$-containing medium led to $\mathrm{Ca}^{2+}$ concentration elevation in mitochondria matrix. It was shown that low $\mathrm{Ca}^{2+}$ concentration in the matrix correlated with the increase in mitochondria size, whereas high $\mathrm{Ca}^{2+}$ concentration correlated with relatively smaller size of the organelles. Activation of the soluble adenylyl cyclase by $\mathrm{NaHCO}_{3}$ with simultaneous inhibition of phosphodiesterase by theophylline was accompanied by the decline in $\mathrm{Ca}^{2+}$ probe normalized fluorescence in mitochondria matrix under conditions of exogenous $\mathrm{Ca}^{2+}$ introduction. It was suggested that the soluble adenylyl cyclase may be involved in regulation of $\mathrm{Ca}^{2+}$ concentration in mitochondria matrix.

Keywords: mitochondria matrix, $\mathrm{Ca}^{2+}$, Fluo-4, adenylyl cyclase.

$\mathrm{M}$ itochondria are high-energy organelles, which conduct a range of important functions in the cell [1]. They take part in calcium signaling, mechanisms of apoptosis, stress adaptation, steroidogenesis and ageing [2]. Dysfunction of mitochondria is one of the reasons of several neurodegenerative diseases and different forms of oncology [3, 4]. Ion channels and ion transporters regulate mitochondria state and functionality directly [5]. Thus, muscles can be functionally active just on condition of corresponding calcium concentra- tion. On the one hand, activation of metabolic pathways in mitochondria by calcium ions through the Krebs cycle and electron transport chain leads to an increase in ATP synthesis [6]. On the other hand, an excessive increase of $\mathrm{Ca}^{2+}$ concentration in mitochondria leads to apoptosis. Therefore, functional activity of mitochondria depends on the ionized calcium content in these organelles. That is why investigation of the ways to influence the $\mathrm{Ca}^{2+}$ transport and accumulation in mitochondria is an urgent issue.

(C) 2021 Sylenko A. V. et al. This is an open-access article distributed under the terms of the Creative Commons Attribution License, which permits unrestricted use, distribution, and reproduction in any medium, provided the original author and source are credited. 
In the previous works, it has been shown that ionized calcium concentration in mitochondria matrix on condition of absence of exogenous $\mathrm{Ca}^{2+}$ depends on incubation medium: in $\mathrm{Mg}^{2+}$,ATP-containing medium this number is a couple of times higher than in $\mathrm{Mg}^{2+}$-containing one. The addition of exogenous $\mathrm{Ca}^{2+}$ to $\mathrm{Mg}^{2+}$ and $\mathrm{Mg}^{2+}$,ATP-containing mediums resulted in an increase of ionized $\mathrm{Ca}^{2+}$ concentration to approximately equal numbers. Nevertheless, the numbers of total calcium accumulation are 30 times higher in the presence of ATP than in its absence [7].

$\mathrm{Ca}^{2+}$ accumulation in mitochondria is provided by $\mathrm{Ca}^{2+}$-uniporter, the activity of which is dependent on the membrane potential of these organelles $[8,9]$. Thus, in $\mathrm{Mg}^{2+}$,ATP-containing medium, the mitochondria membrane is polarized, whereas in $\mathrm{Mg}^{2+}$ containing medium, it is depolarized. Therefore, the question arises as to the mechanisms involved in an increase of ionized calcium concentration in mitochondria matrix in the absence of exogenous $\mathrm{Ca}^{2+}$ and in the presence of $\mathrm{Mg}^{2+}$ and ATP, which leads to high rates of total calcium accumulation on condition of further addition of exogenous $\mathrm{Ca}^{2+}$.

Among different signaling pathways, which influence mitochondria function, much attention has recently been paid to cAMP signaling [10, 11]. Adenylyl cyclase system affects a variety of indicators, including the level of ATP and $\mathrm{Ca}^{2+}$ [12].

Thus, the aim of this work was to study the mechanisms of ionized calcium concentration change in mitochondria matrix in the absence of exogenous $\mathrm{Ca}^{2+}$ and in the presence of $\mathrm{Mg}^{2+}$ and ATP.

\section{Materials and Methods}

The treatment of the lab animals was carried out according to "European Convention for the Protection of Vertebrate Animals used for Experimental and Other Scientific Purposes" (Strasbourg, 1986). Animals were euthanized by chloroform followed by cervical dislocation. After that, their uteri were promptly removed. Mitochondria from myometrium of non-pregnant rats were isolated using the differential centrifugation method [13]. The mitochondria were suspended in a medium with the following composition: $250 \mathrm{mM}$ sucrose, $1 \mathrm{mM}$ EGTA, $20 \mathrm{mM}$ Hepes, and buffered $\mathrm{pH} 7.4$ at $4^{\circ} \mathrm{C}$. Fatty acid free bovine serum albumin $(0.1 \% \mathrm{w} / \mathrm{v})$ was also added. The protein concentration of the mitochondrial fraction was determined by Bradford assay [14]. The concentration of mitochondrial protein in the sample was $25 \mu \mathrm{g} / \mathrm{ml}$.
The hydrodynamic diameter of mitochondria in different mediums was investigated with the method of dynamic light scattering, using Zeta Sizer-3 (Malvern Instruments, UK) with Multi8 computing correlator 7032ce type. Incubation medium contained $20 \mathrm{mM}$ HEPES, $250 \mathrm{mM}$ sucrose, $5 \mathrm{mM}$ succinate, $2 \mathrm{mM} \mathrm{K}$-phosphate buffer, $\pm 3 \mathrm{mM} \mathrm{MgCl}_{2}$ and \pm 3 mM ATP.

Free calcium concentration in the mitochondria $\left(\left[\mathrm{Ca}^{2+}\right]_{\mathrm{m}}\right)$ from rat myometrium was determined using the QuantaMasterTM 40 spectrofluorometer (Photon Technology International) and the fluorescent probe Fluo-4, AM $\left(\lambda_{\text {exc }}=490 \mathrm{~nm}, \lambda_{\text {em }}=520 \mathrm{~nm}\right)$. Myometrial mitochondria were loaded with $2 \mu \mathrm{M}$ Fluo-4, $\mathrm{AM}$ for $30 \mathrm{~min}$ at $37{ }^{\circ} \mathrm{C}$ in a medium with the following composition (mM): sucrose - 250, EGTA - 1, Hepes - 20; pH 7.4. Thereafter, the suspension of mitochondria was diluted (1:10) in the same medium containing no fluorescence probe followed by centrifugation. The pellet was resuspended in the same medium containing no fluorescence probe. The $\left(\left[\mathrm{Ca}^{2+}\right]_{\mathrm{m}}\right)$ was measured in a medium containing $(\mathrm{mM})$ : sucrose $-250, \mathrm{~K}^{+}$-phosphate buffer -2 , sodium succinate $-5, \mathrm{MgCl}_{2}-3, \pm \mathrm{ATP}-3, \pm \mathrm{CaCl}_{2}-$ 0.1, Hepes -20 ; $\mathrm{pH} 7.4$.

The calibration of the Fluo-4 fluorescence was performed at the end of the experiments by adding $0.1 \%$ Triton X-100 and, in $1 \mathrm{~min}, 5 \mathrm{mM}$ EGTA (fluorescence intensities $\mathrm{F}_{\max }$ and $\mathrm{F}_{\text {min }}$, respectively). The concentration of ionized $\mathrm{Ca}$ in the mitochondria matrix was calculated using the Grynkiewicz equation [14].

\section{Results and Discussion}

Dependence of ionized calcium concentration in matrix on ATP and calculating the Hill coefficient. Results of ionized calcium concentration measurements in mitochondria matrix in the absence of exogenous $\mathrm{Ca}^{2+}$ have shown that this number is higher after an incubation in $\mathrm{Mg}^{2+}$,ATP-containing medium than after incubation in $\mathrm{Mg}^{2+}$-containing medium (Fig. 1).

After getting these results, the questions, whether the concentration of ionized calcium in mitochondria matrix depends on ATP concentration in an incubation medium and on the absence of exogenous $\mathrm{Ca}^{2+}$ and, if so, what mechanisms underlie this process, were raised. At constant $\mathrm{Mg}^{2+}$ concentration $(3 \mathrm{mM})$, an increase of ATP concentration in the incubation medium was accompanied by an increase of ionized calcium concentration in mito- 


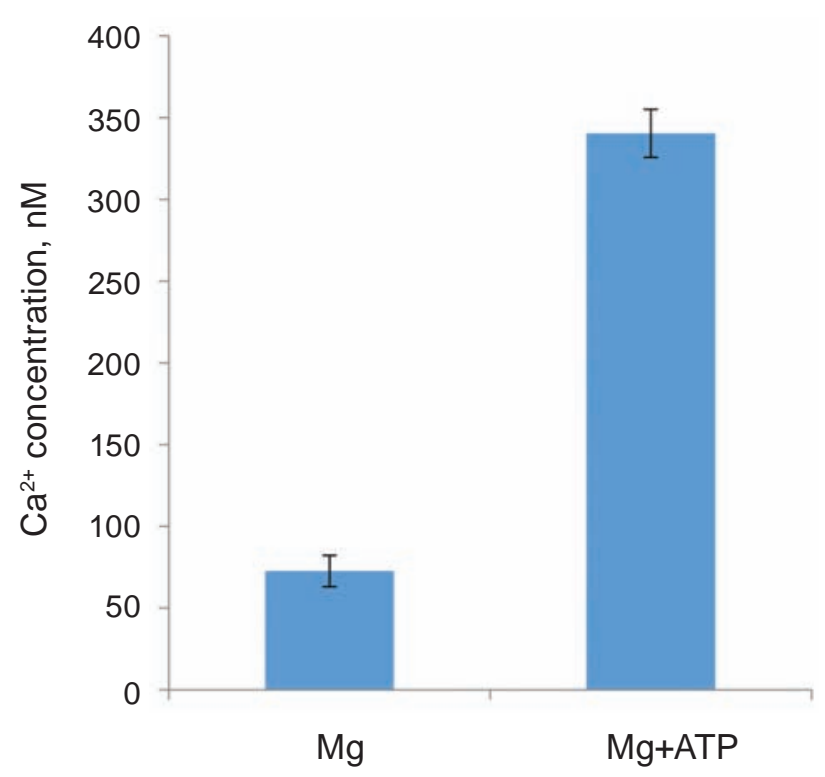

Fig. 1. $\mathrm{Ca}^{2+}$ concentration in mitochondria matrix after their incubation in $\mathrm{Mg}^{2+}$ - and $\mathrm{Mg}^{2+}$, ATP-containing mediums $(M \pm m, n=4)$

chondria matrix with a plateau at ATP concentration over $2 \mathrm{mM}$ (Fig. 2, a). In the presence of $100 \mu \mathrm{M}$ $\mathrm{Ca}^{2+}$ ATP concentration effect was not registered (Fig. 2, b).

Linearization of the obtained results in the coordinates of Hill graph allowed calculating the Hill coefficient. Several evaluations were made, thus the Hill coefficient equals $3.18 \pm 0.27$ and activation constant for ATP equals $0.97 \pm 0.07 \mathrm{mM}$. The rate of Hill coefficient indicates the positive cooperativity, which means that the binding rate of every subsequent ATP molecule is being increased after binding one ATP molecule. Besides, it may also indicate that the effect of ATP on ionized calcium concentration in mitochondria matrix is a multi-stage process. The activation constant for ATP is greatly comparable with physiological ATP concentrations inside of cells. Thus, an ATP-dependent increase of ionized calcium concentration in mitochondria matrix in the absence of exogenous $\mathrm{Ca}^{2+}$ was shown and high rates of total $\mathrm{Ca}^{2+}$ accumulation in condition of further addition of exogenous $\mathrm{Ca}^{2+}$ arising from this was indicated.

The hydrodynamic diameter of mitochondria change after incubation in different mediums. Due to the fact that in the absence of ATP and the presence of exogenous $\mathrm{Ca}^{2+}$, the level of total calcium accumulation in mitochondria matrix is low, this process may be connected to low level of mitochondria membrane potential. Depolarization of mitochondria membrane is usually accompanied by an increase of their hydrodynamic diameter and death.

It was shown that the hydrodynamic diameter of mitochondria was different after incubating it in $\mathrm{Mg}^{2+}$-containing medium and $\mathrm{Mg}^{2+}$,ATP-containing medium: in $\mathrm{Mg}^{2+}$-containing medium it was higher than in $\mathrm{Mg}^{2+}$,ATP-containing one (Fig. 3).

Thus, in the absence of exogenous $\mathrm{Ca}^{2+}$, low $\mathrm{Ca}^{2+}$ concentration in matrix correlates with relatively bigger size of the organelles, which is associated with mitochondria membrane depolarization and organelle death. The high $\mathrm{Ca}^{2+}$ concentration in matrix correlates with relatively smaller size of the organelles, which corresponds to the functional activity of mitochondria in normal conditions.

Which mechanisms underlie the mitochondria hydrodynamic diameter change, caused by presence or absence of ATP in the incubation medium? Perhaps, there may be a role of mitochondrial pore in this process. This is a known fact that adenine nucleotides are blockers of mitochondrial pore [15]. Besides, the mitochondrial pore opening is accompanied by an increase in mitochondria size. We assumed that an increase in mitochondria membrane permeability may be accompanied by an increase of ionized calcium exit from mitochondria matrix. To check this hypothesis, we investigated the ionized calcium concentration in mitochondria matrix in the presence of cyclosporine A, classical blocker of mitochondrial pore.

Investigation of ionized calcium concentration in mitochondria matrix under the influence of several substances. The key regulator of mitochondrial pore is cyclophilin D. Its typical blocker is cyclosporine A [16]. Thus, to study the influence of mitochondrial pore on an increase of $\mathrm{Ca}^{2+}$ concentration in mitochondria matrix, we added $5 \mu \mathrm{M}$ cyclosporine $\mathrm{A}$ to the incubation medium, which also contained $\mathrm{Mg}^{2+}$ or $\mathrm{Mg}^{2+}$,ATP. Using the spectrofluorometer, level of ionized calcium in the organelles was measured. Ionized calcium concentration was calculated with Grynkiewicz equation. As shown in Fig. 4, there were no changes in given parameters. Thus, it was concluded that mitochondrial pore was not likely to be involved in an increase of $\mathrm{Ca}^{2+}$ concentration in mitochondria matrix after incubation in $\mathrm{Mg}^{2+}$,ATP-containing medium in comparison with incubation in $\mathrm{Mg}^{2+}$-containing medium.

Next ATP-dependent process in mitochondria, which could possibly influence the change of ion- 
a

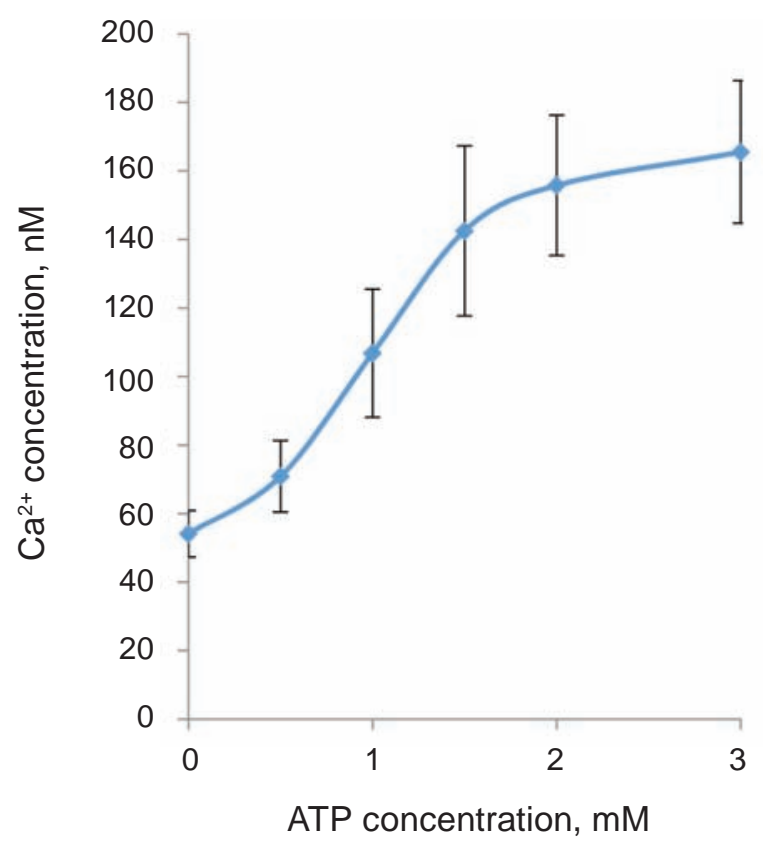

b

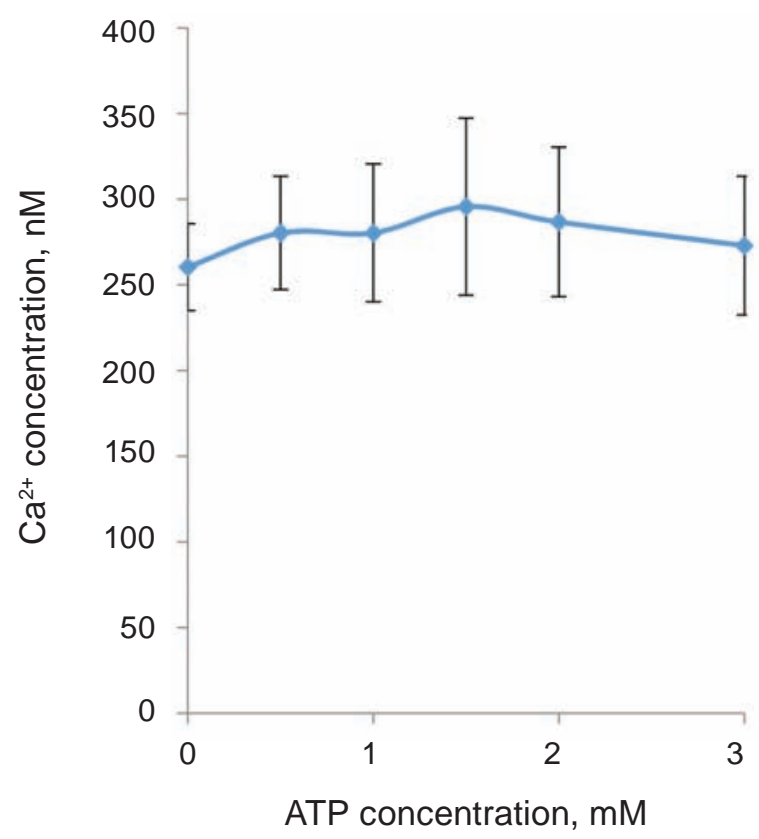

Fig. 2. Ionized Ca concentration in mitochondria matrix at different ATP concentrations: a) in the absence of exogenous $\mathrm{Ca}^{2+}$, b) $100 \mu \mathrm{MCa}^{2+}(\mathrm{M} \pm m, n=6)$

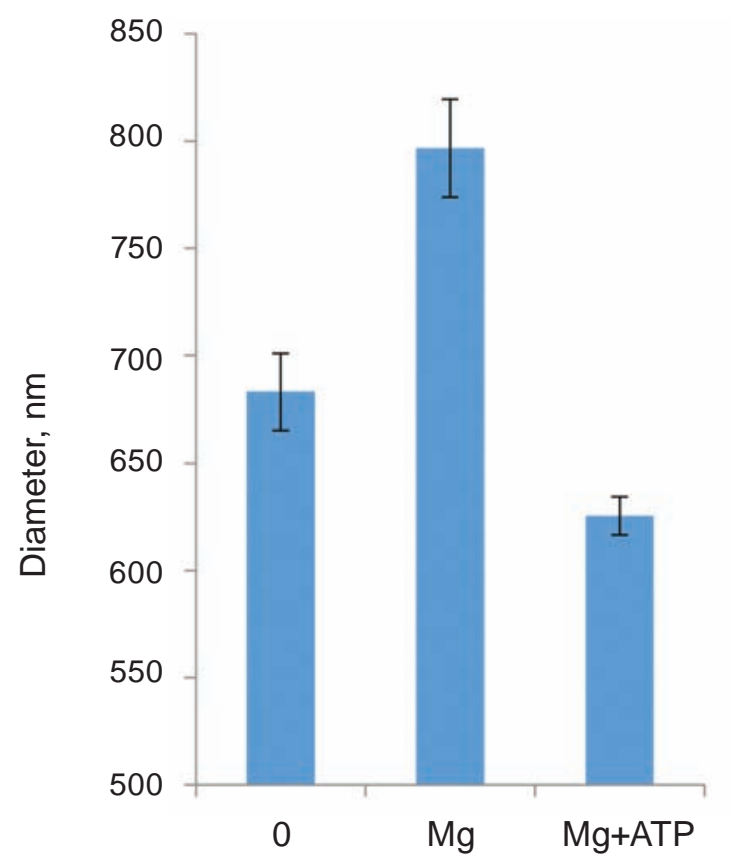

Fig. 3. Hydrodynamic diameter of mitochondria after incubation in medium without $\mathrm{Mg}^{2+}$, with $3 \mathrm{mM}$ $M g^{2+}$ and $3 \mathrm{mM} \mathrm{Mg}^{2+}$, ATP $(M \pm m, n=5)$ ized calcium concentration, is functioning of ATP synthase in the opposite direction, i.e. as $\mathrm{H}^{+}$-ATPase. It is known that the proton pump provides a sufficiently high level of polarization of mitochondria inner membrane, which is a guarantee of high values of total $\mathrm{Ca}^{2+}$ accumulation [17]. Typical inhibitor of $\mathrm{F}_{1} \mathrm{~F}_{0}$ ATP-synthase is oligomycin. Thus, the next step was to investigate the effect of oligomycin in concentration of $0.5 \mu \mathrm{g} / \mathrm{ml}$. Using the spectrofluorometer, level of ionized calcium concentration in the organelles was measured. The results are shown in Fig. 5; it can be seen that $0.5 \mu \mathrm{g} / \mathrm{ml}$ of oligomycin did not have an influence on given parameters.

Thus, a blocker of cyclophilin D (cyclosporine A) and an inhibitor of $\mathrm{F}_{1} \mathrm{~F}_{0} \mathrm{ATP}$-synthase (oligomycin) do not affect an ionized calcium concentration in mitochondria matrix in the absence and the presence of exogenous $\mathrm{Ca}^{2+}$.

Investigation of the role of adenylyl cyclase system in regulation of calcium concentration in mitochondria matrix. Lately, much attention is paid to investigation of mitochondria adenylyl cyclase system, which includes adenylyl cyclase, cAMP, 


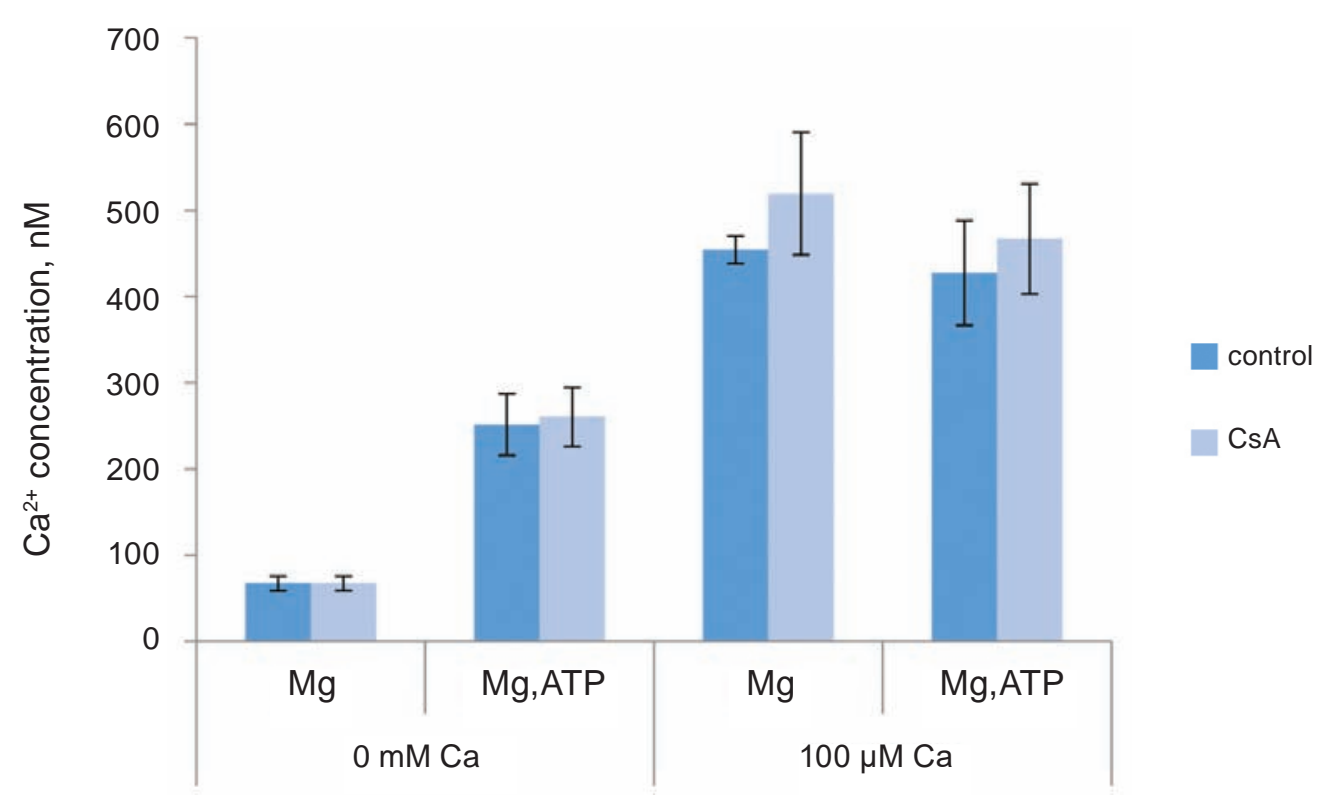

Fig. 4. Ionized calcium concentration in mitochondria matrix in presence of $5 \mu M$ of cyclosporine $A$ in the incubation medium $(M \pm m, n=4)$

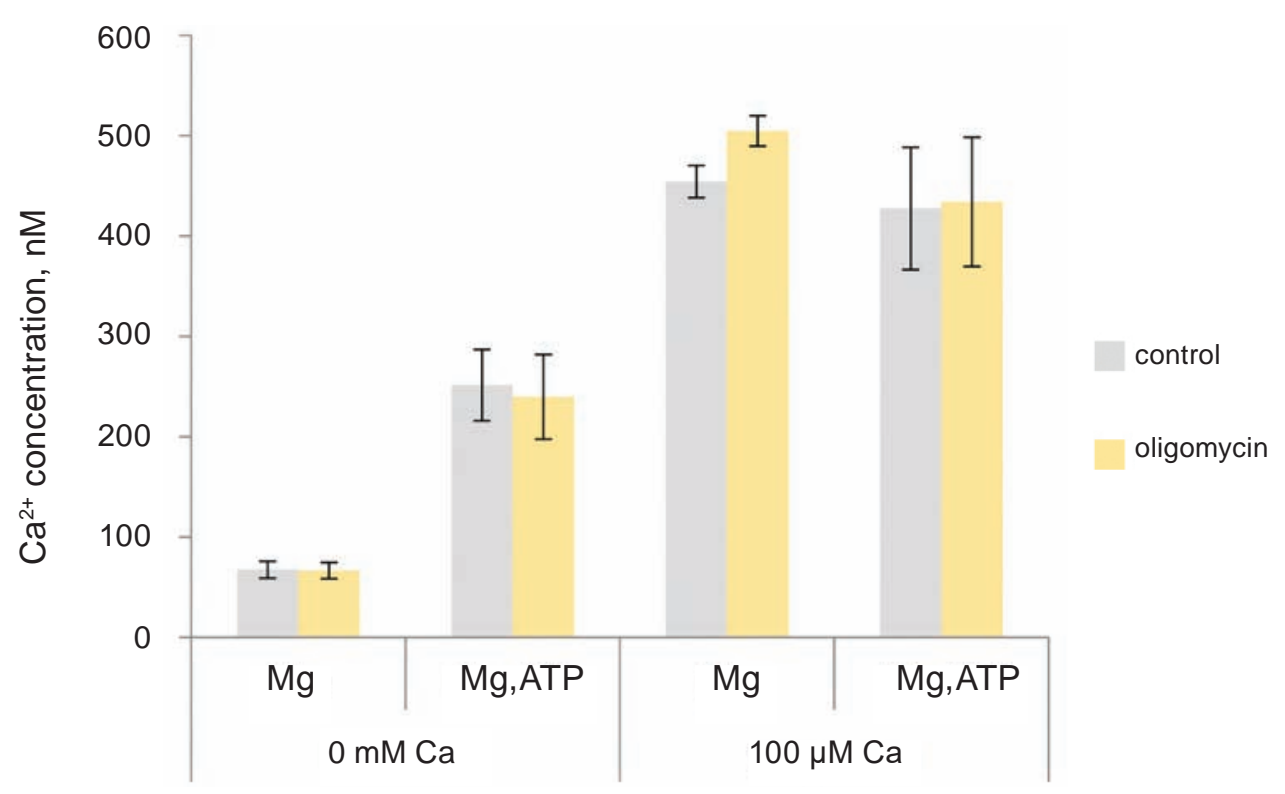

Fig. 5. Ionized calcium concentration in mitochondria matrix in presence of $0.5 \mu \mathrm{g} / \mathrm{ml}$ of oligomycin in the incubation medium $(M \pm m, n=4)$

cAMP-dependent protein kinase A and phosphodiesterase [11]. Membrane form of adenylyl cyclase is activated by forskolin [18]. Although, it has recently been shown that there is a soluble adenylyl cyclase in mitochondria matrix, which is regulated by $\mathrm{NaHCO}_{3}$ [19]. Soluble adenylyl cyclase has ATP binding constant in millimolar concentration range (substrate of adenylyl cyclase). Typical inhibitor of phosphodiesterase is theophylline. It is known that soluble form of cAMP takes part in the regulation of electron transport chain activity, ion channels activity, oxidative phosphorylation, mitochondrial DNA phosphorylation, which influences mitochondria homeostasis, cell survival and apoptosis [19, 20]. Mistakes in these processes lead to a range of pathologies, including metabolism disorders, neurodegenerative disorders, heart diseases, diabetes and different forms of oncology. Besides, new studies 
claim that dysregulation of cAMP signaling pathway is connected to the development of ageing.

We have shown that forskolin with concentrations 10 and $100 \mu \mathrm{M}$ did not have an influence on the $\mathrm{Ca}^{2+}$ concentration in mitochondria matrix (data is not presented). The next step was to measure the ionized calcium concentration in mitochondria matrix under the influence of theophylline and $\mathrm{NaHCO}_{3}$. Incubation was conducted in $\mathrm{Mg}^{2+}$-containing medium in the absence of exogenous $\mathrm{Ca}^{2+}$.

As it can be seen from the results presented in Fig. 6, addition of mentioned above substances led to an increase of ionized calcium concentration in mitochondria matrix after their incubation in $\mathrm{Mg}^{2+}-$ containing medium. Thus, it was shown that activation of adenylyl cyclase in the presence of $30 \mathrm{mM}$ $\mathrm{NaHCO}_{3}$ with simultaneous inhibition of phosphodiesterase by $10 \mathrm{mM}$ theophylline was accompanied by an increase in ionized calcium concentration in mitochondria matrix $(P<0.05)$.

The next step was to analyze the kinetics of changes in the normalized fluorescence of $\mathrm{Ca}^{2+}$ sensitive probe Fluo- 4 in response to the addition of exogenous $\mathrm{Ca}^{2+}$. Normalized fluorescence is calculated with the data received from spectrofluorometer. The values of the fluorescence intensity of the probe after the addition of exogenous $\mathrm{Ca}^{2+}$ are divided by the values of the fluorescence intensity of the probe before the addition of exogenous $\mathrm{Ca}^{2+}$. A graph of normalized fluorescence is constructed based on the obtained results (Fig. 7).

As it can be seen in Fig. 7, activation of soluble adenylyl cyclase by $\mathrm{NaHCO}_{3}$ with simultaneous inhibition of phosphodiesterase by theophylline is accompanied by a decrease in normalized fluorescence in $\mathrm{Mg}^{2+}$-containing medium. The decrease in normalized fluorescence after the addition of exogenous $\mathrm{Ca}^{2+}$ indicates an increase in functional activity of the organelles, as we have shown previously [7]. Thus, it was shown that ionized calcium concentration in mitochondria matrix in the absence of exogenous $\mathrm{Ca}^{2+}$ is higher after incubation in $\mathrm{Mg}^{2+}$,ATP-containing medium than after incubation in $\mathrm{Mg}^{2+}$-containing medium. An increase of ATP concentration in the incubation medium was accompanied by an increase of ionized calcium concentration in mitochondria matrix, the Hill coefficient equals $3.18 \pm 0.27$. The rate of Hill coefficient indicates that the effect of ATP on ionized calcium concentration in mitochondria matrix is a multistage process. One of the possible mechanisms is the regulation of soluble adenylyl cyclase activity. It

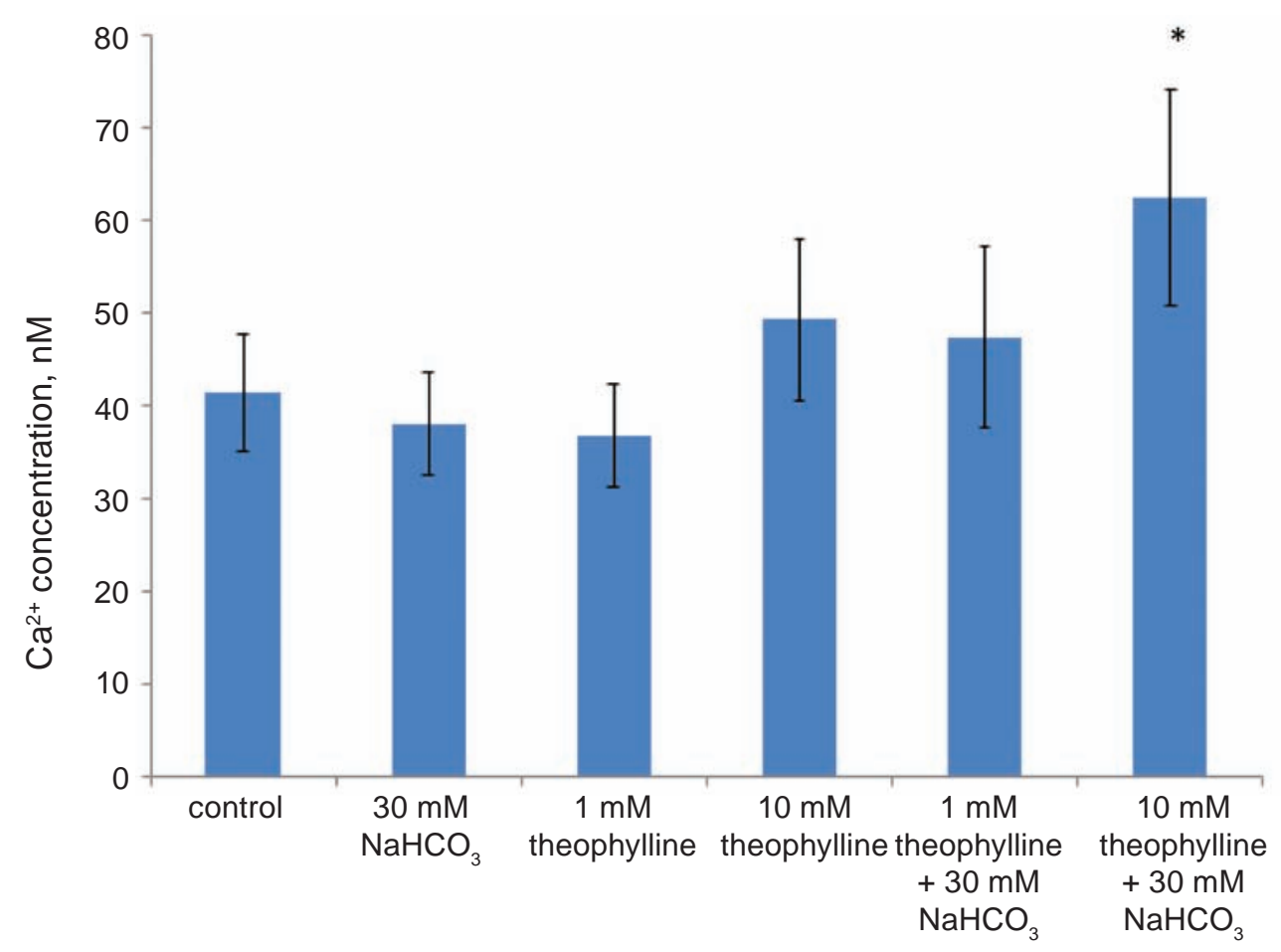

Fig. 6. Ionized calcium concentration in mitochondria matrix in the presence of theophylline and $\mathrm{NaHCO}_{3}$, $\mathrm{Mg}^{2+}$-containing incubation medium $(M \pm m, n=6, P<0.05)$. 


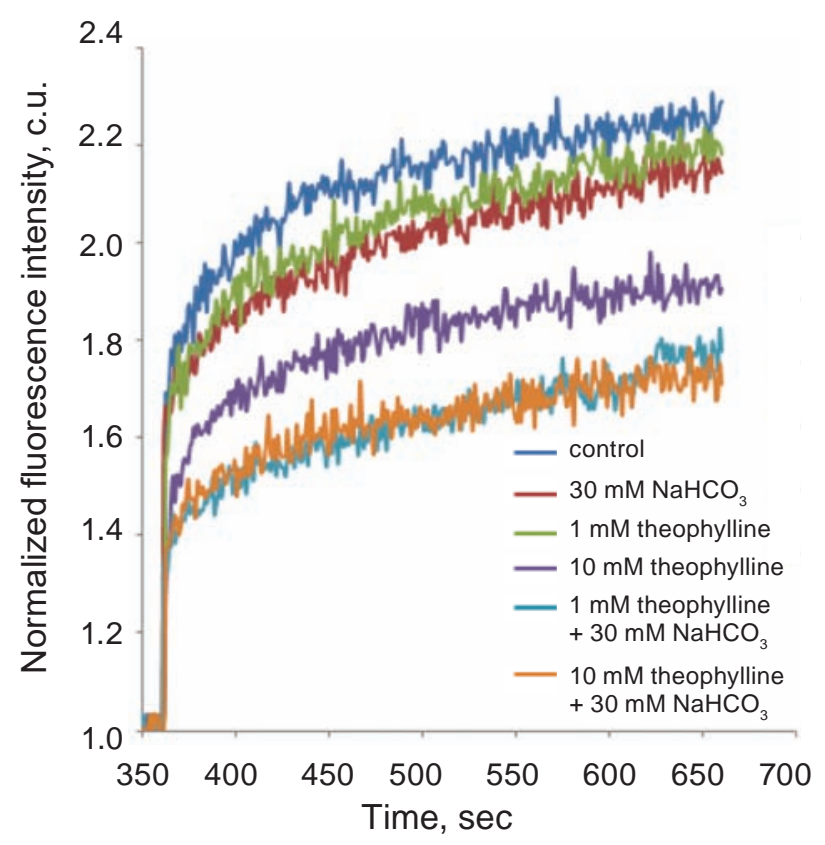

Fig. 7. Normalized fluorescence intensity of Fluo-4 $A M$ in mitochondria matrix under the influence of theophylline and $\mathrm{NaHCO}_{3}$. The results of the typical experiment are presented; $n=6$

was shown that activation of adenylyl cyclase in the presence of $30 \mathrm{mM} \mathrm{NaHCO}_{3}$ with simultaneous inhibition of phosphodiesterase by $10 \mathrm{mM}$ theophylline was accompanied by an increase in ionized calcium concentration in mitochondria matrix. It has been suggested that the soluble adenylyl cyclase may be involved in ionized calcium concentration regulation in mitochondria matrix.

Conflict of interest. Authors have completed the Unified Conflicts of Interest form at http://ukrbiochemjournal.org/wp-content/uploads/2018/12/ coi_disclosure.pdf and declare no conflict of interest.

Funding. The work was conducted on budget costs of NAS of Ukraine, project No 0119U002508.

\section{РЕГУЛЯЦІЯ КОНЦЕНТРАЦІї \\ ІОНІЗОВАНОГО КАЛЬЦІЮ В МАТРИКСІ МІТОХОНДРІЙ ЗА ВІДСУТНОСТІ ЕКЗОГЕННОГО Са ${ }^{2+}$}

\author{
А. В. Силенко ${ }^{\bowtie}$, С. Г. Шликов, Л. Г. Бабіч, \\ О. Ю. Чуніхін, С. О. Костерін
}

\author{
Інститут біохімії ім. О. В. Палладіна \\ НАН України, Київ; \\ 凶e-mail: sylenkoanna@ukr.net
}

Функціональна активність мітохондрій залежить від вмісту іонізованого кальцію в їхньому матриксі. З'ясування можливих способів впливу на транспорт і накопичення $\mathrm{Ca}^{2+}$ в цих органелах $є$ актуальним. Метою роботи було оцінити концентрацію іонізованого кальцію в матриксі мітохондрій за відсутності екзогенного $\mathrm{Ca}^{2+}$ та у присутності $\mathrm{Mg}^{2+}$ і АТР в середовищі. Концентрацію іонізованого кальцію в мітохондріях, ізольованих із міометрія невагітних щурів, вимірювали флуоресцентним зондом Fluo-4 AM, гідродинамічний діаметр мітохондрій оцінювали методом динамічного розсіювання світла. Виявлено залежне від концентрації АТР зростання концентрації іонізованого кальцію в матриксі мітохондрій за відсутності екзогенного $\mathrm{Ca}^{2+}$ та високий рівень загальної акумуляції $\mathrm{Ca}^{2+}$ після внесення екзогенного катіона. Вплив АТР на концентрацію іонізованого кальцію не залежав від блокування мітохондрійної пори циклоспорином А та від інгібування $\mathrm{H}^{+}$-АТРази/АТР-синтази олігоміцином. Натомість, внесення до $\mathrm{Mg}^{2+}$ середовища $10 \mathrm{мM}$ теофіліну та $30 \mathrm{MM} \mathrm{NaHCO}$ супроводжувалось зростанням концентрації $\mathrm{Ca}^{2+}$ в матриксі мітохондрій. Показано, що мітохондрії мають відносно більший розмір за низької концентрації $\mathrm{Ca}^{2+}$ в матриксі, але менший 
розмір вищої концентрації катіона в матриксі. Активація розчинної аденилілциклази додаванням $\mathrm{NaHCO}_{3}$ на фоні одночасного інгібування фосфодіестерази теофіліном супроводжувалась зниженням нормованої флуоресценції $\mathrm{Ca}^{2+}$-чутливого зонда в мітохондріальному матриксі. Зроблено припущення, що розчинна аденилілциклаза може бути задіяна в регуляції концентрації іонізованого кальцію в матриксі мітохондрій.

К л ю чо в і с ло ва: матрикс мітохондрій, $\mathrm{Ca}^{2+}$, Fluo-4, аденилілциклаза.

\section{References}

1. Duchen MR. Mitochondria and calcium: from cell signalling to cell death. J Physiol. 2000; 529(Pt 1): 57-68.

2. Picard M, Wallace DC, Burelle Y. The rise of mitochondria in medicine. Mitochondrion. 2016; 30: 105-116.

3. Duchen MR, Verkhratsky A, Muallem S. Mitochondria and calcium in health and disease. Cell Calcium. 2008; 44(1): 1-5.

4. Grasso D, Zampieri LX, Capelôa T, Van de Velde JA, Sonveaux P. Mitochondria in cancer. Cell Stress. 2020; 4(6): 114-146.

5. Samanta K, Douglas S, Parekh AB. Mitochondrial calcium uniporter MCU supports cytoplasmic $\mathrm{Ca}^{2+}$ oscillations, store-operated $\mathrm{Ca}^{2+}$ entry and $\mathrm{Ca}^{2+}$-dependent gene expression in response to receptor stimulation. PLoS One. 2014; 9(7): e101188.

6. Tarasov AI, Griffiths EJ, Rutter GA. Regulation of ATP production by mitochondrial $\mathrm{Ca}^{2+}$. Cell Calcium. 2012; 52(1): 28-35.

7. Babich LG, Shlykov SG, Kushnarova-Vakal AM, Kupynyak NI, Manko VV, Fomin VP, Kosterin SO. The relationship between the ionized $\mathrm{Ca}$ concentration and mitochondrial functions. Ukr Biochem J. 2018; 90(3): 32-40.

8. Dedkova EN, Blatter LA. Calcium signaling in cardiac mitochondria. J Mol Cell Cardiol. 2013; 58: $125-133$.

9. Elustondo PA, Nichols M, Robertson GS, Pavlov EV. Mitochondrial $\mathrm{Ca}^{2+}$ uptake pathways. J Bioenerg Biomembr. 2017; 49(1): 113-119.
10. Di Benedetto G, Pendin D, Greotti E, Pizzo P, Pozzan T. $\mathrm{Ca}^{2+}$ and cAMP cross-talk in mitochondria. J Physiol. 2014; 592(2): 305-312.

11. Zhang F, Zhang L, Qi Y, Xu H. Mitochondrial cAMP signaling. Cell Mol Life Sci. 2016; 73(24): 4577-4590.

12. Di Benedetto G, Scalzotto E, Mongillo M, Pozzan T. Mitochondrial $\mathrm{Ca}^{2+}$ uptake induces cyclic AMP generation in the matrix and modulates organelle ATP levels. Cell Metab. 2013; 17(6): 965-975.

13. Kosterin SA, Bratkova NF, Kurskiy MD. The role of sarcolemma and mitochondria in calciumdependent control of myometrium relaxation. Biokhimiia. 1985; 50(8): 1350-1361. (In Russian).

14. Bradford MM. A rapid and sensitive method for the quantitation of microgram quantities of protein utilizing the principle of protein-dye binding. Anal Biochem. 1976; 72(1-2): 248-254.

15. Giorgio V, von Stockum S, Antoniel M, Fabbro A, Fogolari F, Forte M, Glick GD, Petronilli V, Zoratti M, I Szabó, Lippe G, Bernardi P. Dimers of mitochondrial ATP synthase form the permeability transition pore. Proc Natl Acad Sci USA. 2013; 110(15): 5887-5892.

16. Hausenloy DJ, Boston-Griffiths EA, Yellon DM. Cyclosporin A and cardioprotection: from investigative tool to therapeutic agent. $\mathrm{Br} J$ Pharmacol. 2012; 165(5): 1235-1245.

17. Duchen MR. Mitochondria in health and disease: perspectives on a new mitochondrial biology. Mol Aspects Med. 2004; 25(4): 365-451.

18. Bitterman JL, Ramos-Espiritu L, Diaz A, Levin LR, Buck J. Pharmacological distinction between soluble and transmembrane adenylyl cyclases. J Pharmacol Exp Ther. 2013; 347(3): 589-598.

19. Valsecchi F, Konrad C, Manfredi G. Role of soluble adenylyl cyclase in mitochondria. Biochim Biophys Acta. 2014; 1842(12 Pt B): 2555-2560.

20. Jakobsen E, Lange SC, Andersen JV, Desler C, Kihl HF, Hohnholt MC, Stridh MH, Rasmussen LJ, Waagepetersen HS, Bak LK. The inhibitors of soluble adenylate cyclase 2-OHE, KH7, and bithionol compromise mitochondrial ATP production by distinct mechanisms. Biochem Pharmacol. 2018; 155: 92-101. 